\title{
The Causal Efficacy of Nature in the Neoplatonica Arabica
}

\author{
Bethany Somma \\ Ludwig-Maximilians-Universität München
}

The place of nature within Neoplatonic metaphysical structures is a tricky subject. Thinkers such as Plotinus and Proclus needed nature to account, in part, for the way in which the soul relates to the body. But given its distance from the first cause and its ambiguous relation to soul, nature often seems to inhabit the penumbra of causal reality. That the causal structure explicated in the Arabic translations of Plotinus's and Proclus's philosophical works was massively influential has been established and is undisputed. While scholars have extensively investigated the causal edifice found in the Neoplatonica Arabica with respect to the higher-level causality of the first cause, the causal efficacy of nature found in these texts remains an open issue. One finds this indeterminacy reflected in recent literature on the concept of nature in Philosophy of the Islamic World. In his examination of the concept of active nature in Abū Bišr Mattā Ibn Yūnus's commentary on Aristotle's Physics, Damien Janos argued that the Arabic Plotinus and Proclus texts are red herrings in attempts to trace the lineage of the notion of a nature as an active principle. ${ }^{1} \mathrm{He}$ argued that in the Arabic Plotinus nature is "subjected to Soul and is merely an instrument or intermediary through which Soul and the higher principles can exercise their activity," while dismissing the Arabic Proclus by pointing to the fact that the Kitāb fi hayr al-mahd "has virtually nothing to say about nature." ${ }^{2}$ His discussion of the texts helpfully pinpoints the causal difficulties found in a Neoplatonic system, difficulties nature epitomizes, namely, whether it is possible for a principle so far from the first cause to be causally efficacious at all, and whether, if this principle is causally efficacious, this efficacy is in any way independent from the higher causes. Recently, Andreas Lammer has disputed the claim that the Neoplatonic texts are unconnected to the notion of nature as an active principle by emphasizing the conceptual distinction between soul and nature

1 Janos 2015, p. 135-177.

2 Janos 2015, p. 155, 154, respectively.

(C) KONINKLIJKE BRILL NV, LEIDEN, THE NETHERLANDS, 2022 | DOI:10.1163/9789004501331_013 
clearly present in all the relevant texts. ${ }^{3}$ As a result, it is yet unclear whether one may rightly identify nature as an autonomous, active cause, or as a cause at all. In this study, I aim to examine nature's causal efficacy within the Arabic translations of Plotinus's and Proclus's texts, and to argue that one does find an account of nature as an active, and to some degree, autonomous cause.

There are two distinct difficulties in an attempt to assess nature's causal role in the Neoplatonica Arabica. The first is the textual situation, namely the survival of Arabic translations and the question of what existed in Arabic in the first place. The second is the above-cited particular philosophical difficulty inherent to the question of nature within a Neoplatonic context, namely, in what way one can say that the lowest causal principle is causally efficacious. I do not propose here to do anything to expand the limited textual situation. The second difficulty is rather that which I am interested in addressing. However, in order to take seriously the question of nature's causal efficacy in the Arabic versions of Plotinus and Proclus, I will be as comprehensive as possible by examining all the relevant and available texts, especially to determine whether and to what extent the two textual traditions might differ on this point, since the causal theory of the Arabic Proclus texts was heavily adjusted and brought into general agreement with the doctrine of Plotinus. I find an attempt to answer this second question compelling on two fronts. First, it provides one with an opportunity to consider causation within perhaps the prickliest end of Neoplatonic structural emanation. A basic tension within Neoplatonic metaphysics centers around causal transitivity: If the first principle is taken to be a cause in the most powerful or truest sense, Neoplatonists bear the onus of delineating the way(s) in which other causal principles may be rightly called causes. This tension is felt nowhere more strongly than in the case of nature, since nature is furthest from the true cause and the progenitor of corruptible products. The difficulty in identifying nature's causal reality is reflected in Plotinus's own discussions of nature, where it is frequently but not always conflated with a lower part of the soul. ${ }^{4}$ The role of nature in Proclus's own system is not as abstruse, but here our two difficulties intersect, since the primary text in which Proclus discusses nature was not fully translated into Arabic, although even within his complete corpus, there are tensions around the fact that nature is both an immanent principle and a goddess. ${ }^{5}$ More on this below. Second, an

3 Lammer 2018, p. 258, n. 147.

4 On nature in Plotinus, see, for example, Enneads v.2(11).1.23-28, IV.4(28).18.4-9, IV.4(28).29.17, and III.8(30).1-6. On the status of Nature in Plotinus, see Wildberg 2009, p. 121-143, and Gerson 2012, p. 17-29.

5 On nature in Proclus, see, for example, Tarrant 2007, p. 103-107. On the status of Nature in 
investigation into nature in the Neoplatonica Arabica is compelling precisely as an attempt to make the Neoplatonic causal structure intelligible and coherent. In both sets of Arabic translations, sense had to be made of the causal relations between the hierarchical levels of reality. The added proclivity to emphasize the causal responsibility of the first cause would also seem to obfuscate the causal power of nature, leaving the situation, as the saying goes, clear as mud.

In this short study, I collect and present the doctrines concerning nature found in the Arabic Plotinus and Arabic Proclus materials. My interest here is primarily philosophical: to determine, given the accessible texts, what account of nature was available as a tool for interpreting nature's causal role. I will be concerned in particular with the way in which one may say that nature is active, by which I mean to what extent it has causal power of its own, and to what extent it is more than a mere instrument of the previous causal power, soul. To address this question, I will proceed as follows. First, I will examine in turn the accounts of nature in the Plotiniana Arabica and Procleana Arabica, identifying the attributes given to nature, and delineating nature's relation to earlier causal principles as well as to its products. I will then briefly compare and contrast the accounts, highlighting two fundamental differences. In conclusion, I will argue that on this evidence, the Neoplatonica Arabica offer an account of nature as an active cause, and as autonomous in a way consistent with a Neoplatonic causal structure. Thus, these texts form a legitimate and important source for discussion of nature in philosophy of the Islamic World, since both corpora offer expositions of nature in which nature is structurally and causally responsible for its products distinct from soul and the higher causal principles. Further, this conclusion indicates that a Neoplatonic theory of an active nature ought to be grouped with the theory found in Aristotelian texts, a theory later criticized by theologians and post-Avicennian thinkers.

\section{Nature in the Plotiniana Arabica}

The Arabic Plotinus corpus, comprising the Theology of Aristotle, Epistle on Divine Science, and the so-called Sayings of the Greek Sage, offers us an imperfect view of the Plotinian materials available in Arabic. ${ }^{6}$ Translation and paraphrase of selections from Enneads IV-VI, they concern primarily discussion

Proclus see Martijn 2010, p. 39-65 and 297-299; Lernould 2012, p. 68-102; and Opsomer 2017, p. 139-166, esp. 152-153.

6 See the seminal article, Zimmermann 1986, p. 110-240; see more recently D'Ancona 2004, p. 159-176; and also D'Ancona 2001, p. 78-85. 
of soul, although the prologue to the most extensive collection, the Theology, professes to fill the theological hole present in Aristotelian philosophy. ${ }^{\text {'Abd }}$ al-Rahman Badawī edited, among other related material, the Theology and, as he named it, the Epistle on Divine Science in 1955, and Franz Rosenthal edited the Sayings of the Greek Sage, as al-Šahrastāni named them, in three waves in the 195 os. $^{8}$ More recently, Elvira Wakelnig edited and translated the Bodleian manuscript Marsh 539, which contains previously unedited selections of the Arabic Plotinus corpus, which Geoffrey Lewis grouped within the Sayings of the Greek Sage in his 1959 translation. ${ }^{9}$

As I discussed above, these texts have been studied at length, particularly regarding questions of metaphysics or theology. Nevertheless, the texts are not completely bereft of discussion of nature. I will argue in this section that one finds a developed theory of nature in the Arabic Plotinus corpus, and that this theory develops more intensely that which is found in Greek original. This last point goes in two directions. Since the theory of nature presented in Plotinus's texts is inconsistent and to some degree underdeveloped, the Arabic paraphrase in some parts intensifies the causal responsibility of nature as a principle, and in others emphasizes its status as an instrument of soul and proximate cause of the body. I will proceed by first placing nature within the causal chain proceeding from the First Cause to the physical world, relating it to its progenitor soul and then to its products. This examination will allow us then to identify the attributes of nature, and articulate the extent to which one can say the account of nature in the Plotiniana Arabica treats it as an active principle.

One first finds the inclusion of nature as an additional hypostasis below soul in the programmatic details of the prologue to the Theology of Aristotle. ${ }^{10}$ D'Ancona highlights this inclusion of the addition and systemization of this

See Adamson 2017, p. 15. See also D’Ancona 1999, p. 73. See Henry and Schwyzer 1959, p. 486-488; Badawī 1955, p. 3-7. All references to Arabic Plotinus texts will include Lewis's classification as found in his translation in Henry and Schwyzer 1959, the page number of the edition and translation, and the corresponding Arabic I consult in each case.

8 References here refer to Badawī 1955; 1952, p. 461-492; 1953, p. 370-400; and Rosenthal 1955, p. 42-66; and Cureton 1846.

9 Wakelnig 2014.

10 Prooemium Theologiae 14, Lewis, p. 487, Badawī 1955, p. 6. Given the difficulty surrounding the prologue and its relation to the rest of the text, I do not use it and only reference it as acknowledgement of the importance of Nature for the text. On the prologue, its author, and its relation to the Theology, see Adamson 2017, p. 27-48. See also on the prologue D'Ancona 1995, p. 155-194, and ead. 2006, p. 138-143. 
level, and identifies the Plotinian source as v.2(11).1. ${ }^{11}$ The text, which is found in the tenth mimar of the Theology, runs as follows.

For if soul wishes to move toward its cause it moves upwards and if it wishes to bring about an image it moves downwards and originates an image (tabtadicu șanaman), which is sensation and the nature (al-tabĩa) in simple bodies and plants and animals and every substance. ${ }^{12}$

Here we have both an introduction of nature and of the relation between nature and soul, on which nature is an image (șanam), of soul. We find such a characterization elsewhere, in the Arabic translation of IV.4(28).18 and IV.4(28).28. These texts are found in the Sayings of the Greek Sage, and are found in the manuscript Marsh 539 edited by Wakelnig. The following passage highlights the differences between soul and nature.

If someone asks about the difference between soul and nature, we say that soul is first and nature second. Soul is the lasting, subsisting thing and nature the changeable thing. Nature is only the image (șanam) of the soul and it is the soul which makes nature evident. Nature is compared to wax in which a seal-ring is imprinted: part of the imprint is protruding and part sunken. The protruding part is clear and evident, whereas the sunk part is shallow with hardly any impression, and nature resembles the pattern of the sunken imprint. ${ }^{13}$

Added to the description of nature is that it is changeable (mustahill) in contrast to soul's characterization as fixed and enduring (al-ta $\bar{a} b i t$ al-qā'im). Nature is further described by an analogy in which nature ( $\left(a l-\operatorname{tab} \hat{\imath}^{\imath} a\right)$ is said to be like the imprint $\left(a l-t a b^{c}\right)$ in wax from a signet ring. Notable in this example is the fact that the analogue to soul is not identified: it is said only that nature is the worse part of the imprint. The text continues by offering another image, this time one that aims to illustrate the way in which nature acts.

Therefore, it only acts without knowing what it does, because it acts without any will of its own, just as something hot acts on the thing in contact

11 D'Ancona 1999, p. 63. There she also helpfully lists the literature regarding the possibility of this position in Plotinus's own work. See also Adamson 2017, p. 186.

12 Theologia Aristotelis X.16, Lewis, p. 293 altered, Badawī 1955, p. 136.

13 Sayings of the Greek Sage II.6o according to Lewis's organization, Wakelnig 2014, p. 136139, slightly altered. 
with it. For it pours some of its heat over it and thus heats it, yet the heat in the heated [object] is not like the heat in the thing heating [it], but it is weaker and there is less of it in the heated [object]. ${ }^{14}$

Both the lack of thought ascribed to nature and the fire image are true to the Plotinian original, and this image occurs again in more detail later in Sayings of the Greek Sage II.

We want to know how the body must receive soul and nature. Is it like the air which is excited by sunlight or as the air heated by the heat of fire? So he says that the body is enlivened by the soul only by the mediation ( $b i$ tawassut) of nature. For nature is the effect of soul and body the effect of nature, and the remotest cause is in the remotest effect only by the mediation of the more proximate cause. And he says that the body must be receptive to the soul as air is receptive to the heat of fire. For when fire has produced an impression on air and heated it, and has then vanished from it, fire's heat remains in the air as a trace (rasm). When air is in this condition, it is also quick to receive heat. In the same way the body which is receptive of the soul must be prepared (mutahayyian) for receiving the soul, and this preparation (al-tahayyu') [consists of] the existence of a trace and a shadow of the soul's shadow (rasm wa-zill min zill al-nafs), i.e. nature, in the body. ${ }^{15}$

This passage offers perhaps the clearest presentation of the causal chain of soul, nature, and bodies we find in the Arabic Plotinus corpus. The three stand in cause and effect couples, soul producing nature, and nature bodies. We are also told that soul enlivens body only by nature's mediation, one of the qualifications of nature that suggests its instrumental status. But this apparent instrumentality must be balanced with the other way in which nature is described, namely, as the preparation for soul. This identification of nature as a trace or shadow of soul combined with the notion or preparation illuminates the crux of the issue. ${ }^{16}$ This description of nature as the preparation might be taken to mean that before soul is capable of intervening in the situation of bodies, nature must be at work, preparing. If we interpret the passage in this way, we

\footnotetext{
14 Sayings of the Greek Sage II.61 according to Lewis's organization, Wakelnig 2014, p. 138-139.

15 Sayings of the Greek Sage II.73-76 according to Lewis's organization, Wakelnig 2014, p. 14O141.

16 On the trace of soul in Plotinus's own philosophy, see Noble 2013, p. 249-279.
} 
might say that nature has access to a mode of being that is beyond soul's immediate reach, namely, that bodily existence is off-limits as it were, unless soul can work together with nature. An important implication in this case might be that nature can work independently from soul. But another way of interpreting nature as the preparation of bodies for soul might simply be that nature's preparation is the fact of soul's intervention in bodies in the first place, that is, nature's preparation is soul's intervention. On this reading, soul prepares bodies, and nature is the tool by which it does so. However, this second reading is insufficient as it stands. It is not the fact that nature is some kind of continuation of soul that renders it instrumental. This continuation is the backbone of a Neoplatonic structure, and in itself would undermine soul's own claim to being a distinct hypostasis. ${ }^{17}$ Stated in other words, the fact that something is an extension of its prior cause can never in and of itself be a sufficient reason to reject the substantiality of the product - otherwise everything but the first cause will have to go. If we take this proviso into account, the difference between the two interpretations becomes rather blurry. What should rather concern us is the earlier qualification in that nature "has no will of its own," suggesting that it is incapable of directing anything autonomously at all. Now we must consider whether we find any evidence that nature has some kind of independent causal efficacy given this current assessment.

Let us thus turn to a consideration of the relation between nature and intellect. Just before the fire image discussed above, we find an explanation of nature's relation to the intellect, which goes as follows.

When the intellect has poured its power over the being of the soul, the soul has been formed at that [time]. Thereupon the soul has poured its power over matter and shone its rays over it, and then nature has been formed. Nature is the soul's imagining and one of its rays. Nature is the last of the intellectual things, for the intellectual things come from the first intellect until they finally reach nature where they stop. As for things which are posterior to nature, they are images and traces of the intellectual things, yet we must know that nature acts and is acted upon by itself. As for the thing prior to it, namely the soul, it acts and is not acted upon either by itself or by nature. As for the thing above soul, namely intellect, it acts neither on matter nor on bodies, for matter is only a trace of its

17 Here I refer to the description of soul as an extension of the intelligible substance of intellect, cf. Epistle on Divine Science 78, Lewis, p. 311, Badawī 1955, p. 172-173, and Theology of Aristotle 1.2, Lewis p. 219, Badawī 1955, p. 18-19. 
trace, namely of soul, and the bodies are a trace of the trace of its trace, namely of nature. For it is nature which generated the first bodies, i.e. the elements. ${ }^{18}$

This rich passage more exactly situates nature within the causal chain, identifying it alongside matter as one of two products of soul. We also find additional characterizations of nature. First, we are told that nature is the last of the intellectual things, al-ašyä al-'aqliyya. This point we will find echoed in a moment. Second, we learn that nature's own products are images and traces (aṣnām warusūm) of intellectual things and that the elements are an example of nature's own products. Third, we are told that nature acts and is acted upon by its own self, which is also clarified by the following passage.

When matter receives form from the soul nature is originated, then it informs nature and makes it receptive to generation (li-l-kawn) by compulsion. It is because of the power of soul and the high causes that have been put in her that nature becomes receptive to generation. The action of the mind stops at nature and the beginning of generation. Generation is the last of the intellectual formative causes (al-ilal al'aqliyya l-musawwira) and the first of the engendering causes (al-ilal almukawwina), and of necessity the active causes (al-ilal al-fawäil) that form substances (al-musawwira li-l-jawāhir) cannot stop before they come to nature. ${ }^{19}$

With this passage from the Theology we find some clarity regarding the nature's causal function. First, nature's position as the last in the line of intellectual things is identified as the beginning of generation. This second point makes explicit in what way nature can be said to a be a cause distinct from soul, since in this passage nature seems to be identified with the beginning of generation. It is for this reason that nature is said to act and be acted upon by its own self: since nature has been forced to receive generation in order to form generation's beginning, it is necessary that nature, as an immanent causal principle, must itself be amenable to a redefinition of its own design so that it may redirect its effort alongside and within its products. Thus, on this account, nature is the first of the engendering causes, but still explicitly specified as an active cause responsible for forming substances.

18 Sayings of the Greek Sage II.66-70 according to Lewis's organization, Wakelnig 2014, p. 138139 .

19 Theology of Aristotle viI.17-18, Lewis, p. 245 altered, Badawī 1955, p. 86-87. 
In order to spell out further the way in which nature acts, I want to gesture briefly toward the connection between nature and kalimāt, the enmattered activities of soul in body, the translation of the Greek logoi. We learn in Theology viI that nature is specified as that which "dwells in the interior of bodies," described as follows.

Were it not that soul penetrates into the natural bodies and brings about in them its wonderful affections of many activities (al-afācil), continuously-I mean nature - the body would speedily decay and perish and would not abide and bear fruit as it does now. For when the soul sees the splendour and beauty of the body, it imprints nature in it (atara altabīata fihi $)$ and pours forth its exalted power on it and introduces into it active words (al-kalimāt al-fawāil) so that they may perform wonderful activities that astonish the beholder. ${ }^{20}$

In these passages, nature is identified with the different psychic elements that are immanent within bodies, responsible for their activities. Here nature is presented as a synonym for word ( kalima), activity $\left(f^{c} l\right)$, now added to the characterization in Theology of Aristotle VII.17-18 as the last of the active, formative causes (al-ilal al-'aqliyya al-mușawwira), and first of the engendering causes (al-ilal al-mukawwina). In Theology of Aristotle x.64, we find a definition of kalima that explicitly identifies it with activity.

If the soul is not the human being, the human being must then be a word (kalima) other than the word of the soul (kalimat al-nafs). If this is so, what prevents us from saying that the human being is the combination of both soul and body, in which case soul would possess some one of the various words? I mean by 'word' activity $\left(f^{i}\right.$ ) , for the soul has one of the various activities, and it is not possible that there is an activity without an agent. ${ }^{21}$

The connection between kalimāt, the psychic activities in the body, and nature is expressed in the Theology of Aristotle IX.30: "When the soul gives form to matter and originates the simple bodies from it, it bestows on it a natural active word (kalima fa"äla tabíiyya), and the natural active word is from the soul."22

20 Theology of Aristotle viI.28-30, Lewis, p. 247 altered, Badawī 1955, p. 88. Similarly, one could adduce Theology of Aristotle x.64-66.

21 Theology of Aristotle X.64, Lewis, p. 447 altered, Badawī 1955, p. 143-144.

22 Theology of Aristotle IX.30-31, Lewis, p. 181, Badawī 1955, p. 124. 
As a result, there seems to be functional identity between nature, the kalimāt bestowed by soul, and soul's activities.

From what is presented in these passages, I suggest that nature in the Arabic Plotinus corpus is a product of soul that is the manifestation of soul's activities in the body, a distinct stratum of life and cohesion afforded by soul but active nonetheless. The point of the extended discussion of nature is to account for the way in which it allows soul to animate the body. The animator of body must afford both life and unity to body, which it does not have without soul. This point is expressed in the Theology IX, where we read: "Every body, gross or subtle, is one and coherent and is not a cause of its own oneness and cohesion (li-wahdāniyyahīwa-li-ittișâlihī); no, the soul is the cause of the cohesion and oneness of the body." ${ }^{23}$ Nature is the realization and sustenance of this unity and cohesion. I have laid out four distinct descriptions of nature: preparation of body for soul's intervention, intellectual nature, beginning of generation, and an active and formative cause. Thus, although nature is doubtless something generated by soul, and to some degree an extension of soul's activities, we need not conclude that nature has no causal power. After all, we read elsewhere that soul is itself identified simply as the activity of intellect- "The intellect's activity in its entirety is the soul" - and the fire image is even used to express this relationship. ${ }^{24}$ This analogue shows that such a relationship in itself does not preclude causal efficacy on behalf of the product, and nature as the activities of soul in body would be responsible for growth, the arrangements of elements, and in general making the body available for soul's use. The point that tempers nature's causal efficacy is rather the murky situation of its self-directedness. However, again the case of intellect might assuage our concern, since it does not choose to act or not to act, although it is certainly aware of its action and the paradigm of thought: only soul is a mobile agent in this way (of course, this remark is not to say that nature and intellect are causes in the same way or of the same things). Thus, there are philosophically sound grounds on which nature may be taken as an active cause. In fact, we do not even need an uncontroversial picture of nature as active: that it may reasonably be interpreted as active is enough to include its consideration as a source of a meaningful account of nature for philosophers of the Islamic world.

23 Theology of Aristotle IX.47, Lewis, p. 185, Badawī 1955, p. 127.

24 Sayings of the Greek Sage II.9-10 according to Lewis's organization, Wakelnig 2014, p. 124. 
Turning to the Arabic Proclus materials, there are three sets of texts one must consider. ${ }^{25}$ First, there are those texts within the Liber de causis tradition, the Latin translation of the Arabic recension of Proclus's Elements of Theology, which today survives in Arabic as Kitāb al-Idah fi l-Hayr al-Maḥd, known as the Liber de causis I, and in a second version preserved without a title, known now as Liber de causis $\mathrm{II}^{26}$ In this group, we might include the epitomes of the texts made by Abū l-Ḥasan Muḥammad ibn Yūsuf al-'Āmirī in his Kitāb al-Fuṣūl fì l-Ma'ālim al-ilāhiyya and by 'Abd al-Laṭîf al-Bag̉dādī in the twentieth section of his Kitāb fi 'ilm ma $b a^{c} d$ țabía ${ }^{27}$ Further included in this first group is the pseudo-Aristotelian Kitäb al-Haraka, although, as Elvira Wakelnig has shown, in the Kitäb al-Haraka we find similarities to both the Liber de causis tradition and to the Proclus Arabus corpus. ${ }^{28}$ Second, then, is the Proclus Arabus corpus, in which is included other parts of Proclus's Elements of Theology, editions of which are found in Endress's Zwanzig Abschnitte aus der Institutio Theologica in Arabischer Übersetzung and in Zimmermann's "Proclus Arabus rides Again."29 We could also delineate a third group, in order to group together the remaining texts that do not stem from the Elements of Theology, and are mostly on natural philosophy, such as the two Arabic versions of Proclus's commentary on De Aeternitate Mundi and the only surviving fragment of his commentary on the Timaeus..$^{30}$ It is important to highlight that the first and second text groups do overlap, as has been shown convincingly by Wakelnig, and both present propositions originally stemming from Proclus's Elements of Theology. ${ }^{31}$

An investigation into the notion of nature within the surviving Arabic versions of Proclus's philosophy faces a unique challenge, since Proclus's own

25 For overviews of the material available in Arabic and what survives, see Wakelnig 2012a, p. 165-176; and more recently Adamson and Karfík 2017, p. 295-297.

26 The first is found in Badawī 1977; and the second is in Thillet and Oudaimeh 2001-2002.

27 For an edition of al-'̄̄mirī see Wakelnig 2006, and for 'Abd al-Latîf al-Bağdādī see Martini Bonadeo 2017, p. 259-305; for an English translation, see Taylor 1984, p. 236-323; this translation was based largely on the text found in Badawī 1977, p. 248-256. On Proclus's thought in 'Abd al-Latif, see also Martini Bonadeo 2013, p. 242-254.

28 For the text of Kitäb al-Haraka, see the extensive work done by Wakelnig 2013. On the relation of the Kitāb al-Haraka to the surviving translations of the Elements of Theology, see also Wakelnig 2012a, p. 170-176.

29 See Endress 1973, and Zimmermann 1994, p. 8-51.

30 For the first version see Badawī 1977, p. 34-42. For the second version see Wakelnig 2012b, p. 51-95. And for the edition of the Timaeus fragment, see Arnzen 2013, p. 1-45.

31 Wakelnig 2012a, p. 165-176. She also highlights the likelihood of an original, complete Arabic translation of the Elements of Theology, see p. 176 . 
theory of and investigation into nature itself is found in his commentary on the Timaeus. Although we have one fragment from this text, Arnzen, in his edition of the fragment and accompanying letter from Ḥunayn ibn Ishạa, comes to the conclusion that: "We can be quite sure that apart from the fragment preserved in Ms Aya Sofya 3725, no complete or substantial Arabic version of Proclus's commentary on the Timaeus circulated among medieval Arabic writing philosophers." 32 And, unfortunately for us, this fragment does not contain discussion of nature. Although this would seem to damn any investigation into an account of nature found in the Arabic translations of Proclus, one nevertheless finds reference to nature in the Procleana Arabica. To the contrary, there are both references to nature and an incorporation of nature into the causal structure presented in both the Liber de causis text group and in the Proclus Arabus corpus. In this section, I will proceed, as in the previous section, by examining the placement of nature within the causal chain presented in the relevant texts, and examine the relation of nature to the previous causes. Then I will examine the brief description of nature's relation to its products, before moving on to identify what attributes we can say nature has, and then to what extent, if any, we may call nature causally efficacious in the Procleana Arabica.

One of the biggest challenges of working with the Arabic Proclus materials is clearly determining the relation of the different text sets to one another, including the epitomes of the texts. I will here use whatever I find in those texts, all of which go back to the Elements of Theology. As I mentioned above, I do not intend to remark on the textual transmission, but rather to examine the extent to which nature was present in all versions of the text, and to show that these texts had an influence in the transmission of them by al-'Āmirī and 'Abd alLatịf. Let us begin with nature's relation to soul. We find in the so-called Liber de causis I the following description of the soul-nature relation.

Every noble soul possesses three acts: a psychical act ( $f_{i} l$ nafsānī), an intellectual act $\left(f^{\prime} l^{\prime} a q l \bar{\imath}\right)$, and a divine act ( $\left.f^{\prime} l i l a h \bar{\imath}\right)$. By way of the divine act, [the soul] governs nature (tudabbiru al-tabic a) by a power in it from the first cause. By way of the intellectual act the soul knows the things by a power of intellect in it. And by way of the psychical act, the soul moves the first body and all of the natural bodies, because it is the cause of motion of bodies and of the act of nature $\left(f^{i} l a l-\operatorname{tabi}^{i} a\right){ }^{33}$

$32 \quad$ Arnzen 2013, p. 10.

33 Badawī 1977, p. 5, my translation. 
We find the two qualifications of the relationship between soul and nature-that soul governs nature through a divine act and that soul moves natural bodies through its psychical act—reflected in both the epitome of 'Abd al-Lațîf and the paraphrase of al-Āmirī. In 'Abd al-Lațîf's discussion in Chapter 20 of his book on metaphysics, he reiterates the first point, namely that: "From the divine power (quwwa l-ilähiyya) proceeds a divine act ( fil alilāhiyya) by which [the soul] governs nature (tudabbiru al-țabīa)." ${ }^{34}$ This concept of a divine power in charge of nature may also be reflected in al-Āmiri's Kitāb al-Fușul, where we find the following.

The universal soul, I mean the tablet, is ordered by three properties: a divine property, an intellectual property, and an essential property. In accordance with the divine property, [the universal soul] governs the universal nature. According to the intellectual property, [the universal soul] knows things in their reality simultaneously with the fact that it knows them. And according to the essential property, [the universal soul] gives the natural, instrumental bodies form while blowing a gentle wind [of life into them]. ${ }^{35}$

All three passages are variations of Proposition 201 from the Elements of Theology as Wakelnig has shown. ${ }^{36}$

Thus far nature does not seem to have any causal independence, but wholly to be governed and moved by soul. However, in both versions of the Liber de causis and in al-Āmirì there is further specification of the relation of nature to soul that shows that not all natural bodies fall under the provenance of soul. In the Liber de causis I, we read:

Some soul is intellectual soul, because it is connected to intellect, and some of soul is soul alone. Some of natural bodies have soul governing them and taking care of them, and some are natural bodies with no soul. ${ }^{37}$

34 See Martini Bonadeo 2017, p. 293, and a discussion of the sources on p. 270. See Taylor 1984, p. 239.

35 Wakelnig 2006, p. 86-87, my translation. See also her commentary on p. 171-177.

36 Wakelnig 2006, p. 172.

37 Badawī 1977, p. 19-20, my translation. We find the same idea in Liber de causis II Bāb 25: "Some soul is intellectual, because it is attached to the intellect, and some of it is soul alone, like the material soul. Some natural bodies have soul governing them and taking care of them, and some of them are bodies alone, without soul." From Thillet and Oudaimeh 2001-2002, p. 348-349, my translation. 
Thus here there are at least natural bodies outside the sphere of soul. We find this division echoed in al-Āmirī's paraphrase:

Some soul is intellectual soul, because it is attached to the intellect, adhering to its virtue. Some soul is soul alone, because it does not go beyond the measures that happen upon them in this state. And there is nature that is psychical (nafsāniyya), because it is under the governance of the soul, and some of it is nature alone. ${ }^{38}$

Although we read that soul does not govern all natural things, the causal structure of nature is not yet clear. An investigation of the relationship between nature and intellect clarifies nature's causal responsibility.

As is the case in the Arabic Plotinus materials, there is a fundamental connection between nature and intellect. In both versions of the Liber de causis and in 'Abd al-Lațif's epitome, nature's own governance is said to have an intellectual constitution.

Therefore, the intellect is the head of all things that are under it, holding fast to them and governing them, just like nature governs the things that are under it by a power of intellect; and similarly the intellect governs nature by a divine power. ${ }^{39}$

Here we find that in addition to soul, intellect is a source of governance for soul, except we also learn that not only does intellect (as did soul) govern nature by a divine power, nature itself has its own governance of what is below it. One finds nearly the same thought expressed in Liber de causis II, except there nature is said to govern by a power of soul, and intellect is not said to govern nature specifically at all. ${ }^{40} \mathrm{In}$ 'Abd al-Lațîf we find the situation of governance the same as in Liber de causis I, and he says: "The intellect governs nature by a divine power, and nature governs the things that are under it by a power of intellect." ${ }^{11}$ Regardless of the power nature uses to govern the things under it,

38 Wakelnig 2006, p. 96-97. In her commentary on al-Āmirī, Wakelnig helpfully clarifies that "the natural bodies," al-ajrām al-țabĩiyya, not in the original, exists in the Liber de causis I, Liber de causis II, and in al-Āmirī as a mistranslation of the original "bodily nature," $\varphi \dot{\sigma} \sigma \varsigma$ $\sigma \omega \mu \alpha \tau i \dot{\eta}$, in the Elements of Theology 111. See her commentary on p. $253 \mathrm{ff}$.

39 Badawī 1977, p. 12, my translation.

40 Thillet and Oudaimeh 2001-2002, p. 344-345.

41 See Martini Bonadeo 2017, p. 294. See Taylor's translation, Taylor 1984, p. 240. 
what is important there is that nature is said to possess a distinct form of governance at all.

Discussion concerning which parts of the metaphysical hierarchy contain or envelop others is present in all four texts, and follows upon this discussion of nature's governance and its relation to intellect. In Liber de causis I, we find an account of layers of containment:

The intellect encompasses ( $y u h \bar{i} t u)$ natural, generated things (bi-l-akwān al-tabiiyya), and what is above nature, I mean the soul, since it is above nature, and because nature encompasses generation, and soul encompasses nature, and intellect encompasses soul, intellect therefore encompasses all things. ${ }^{42}$

This account is found again in Liber de causis II, where we read: "The intellect encompasses all the generated things, nature, and what is above nature, I mean the soul. And certainly nature encompasses generation, and the soul encompasses nature, and the intellect encompasses the soul. Consequently, the intellect encompasses the totality of things." 43

When we turn to 'Abd al-Lațif, we find a truncated yet slightly adjusted version of this account, and we read that, "Nature encompasses generation, and the soul encompasses nature, and the intellect encompasses soul, and the first cause encompasses intellect." 44 Here the first cause is added as something that encompasses, while the inference that intellect must encompass all things is not explicitly drawn. We further find intellect's encompassing of nature in al'Āmirī's paraphrase, which reads as follows, "The intellect contains the natural generated things, the essence of nature, and the master of nature, I mean the soul." ${ }^{45}$ Wakelnig points toward D'Ancona's suggestion that this passagewhich in various forms is found in Liber de causis I and II, 'Abd al-Lațif and al-Āmirī-is evidence of the influence of the Arabic Plotinus texts on the Arabic Proclus materials. ${ }^{46}$ We find a similar idea in a passage found in the pseudoAristotelian Kitäb al-Haraka, in which the author, while explaining the relation between something that subsists in itself and its cause, offers the following as an example: "We mean that it is fixed ( $\underline{t} \bar{a} b i t)$ in a cause just like nature rather

\footnotetext{
42 Badawī 1977, p. 12, my translation.

43 Thillet and Oudaimeh 2001-2002, p. 344-345, my translation.

44 See Martini Bonadeo 2017, p. 294. See Taylor's translation, Taylor 1984, p. 240.

45 Wakelnig 20o6, p. 92-93, my translation.

46 Wakelnig 2006, p. 222.
} 
is fixed in soul, and soul in intellect, and intellect in the first cause." ${ }^{47}$ Wakelnig has traced in the larger section to which this passage belongs (although not necessarily this particular point) portions of Propositions 41, 45, and 48 of the Elements of Theology, while the other passage in question has not been traced to any one of the propositions. However, the point of both is clear: Nature is encompassed by and remains fixed in soul, such that there is here, as in and perhaps because of the Arabic Plotinus materials, an ontological dependence of nature on soul. Germane for this investigation is the further point that nature is not the lowest rung on the ontological ladder, but rather itself encompasses generation. ${ }^{48}$

Nature's governance and encompassing of generation suggest that nature has some kind of causal power, and the nature of this causal power becomes clearer when considered in conjunction with the delineation of intellect's borders. In Liber de causis II Bāb 2, we read a description of matter and the way in which it receives form.

However, even if it is simple, it is baser and viler, and lower than nature and things that are composite, for it does not have an active power (quwwa $\left.f a^{\text {c }} a \bar{l} l a\right)$ that flows onto something [else], but it has only a receptive power (quwwa qābila) into which the forms flow. Matter is lower than nature and all of the generated things, because [nature] flows its active power over it, and it performs in it its wondrous deeds. ${ }^{49}$

Wakelnig has noted that the talk of the traces, and especially of a trace of a trace, is, as she lucidly states, "not only non-Proclean, but also un-Proclean."50 After the above examination of the traces and impressions used in the Arabic Plotinus materials to describe the soul's relation to the body, this passage becomes yet another instance of the Plotinian influence on these materials. However, most germane to our study is the attribution to nature of a power that it shares with what is beneath it, which I think we can identify as the puissance active that nature allegedly lacks. This attribution of power to nature, a power that brings about effects in what is beneath it, is the first indication that nature is indeed endowed with causal power in Procleana Arabica.

47 Wakelnig 2013.

48 One might consider the point in the Arabic Plotinus that nature is the beginning of generation. See Theology of Aristotle viI.17-18, Lewis, p. 254 altered, Badawī 1955, p. 86-87.

49 Thillet and Oudaimeh 2001-20o2, p. 320-321, my translation.

$5^{\circ} \quad$ Wakelnig 2012a, p. 173 . 
We are, nevertheless, left with the fact that such an attribution is made only once, and even then in a passage that seems to be heavily influenced by Plotinian thought. However, there is another angle from which nature's causal power in its Proclean version may be intensified. Within the Proclus Arabus corpus, we find a direct translation of Proposition 21 of the Elements of Theology, one of the places Proclus most strongly discusses nature as being similar to a monad. Important here is not what Proclus himself really thought about nature and monads, but the fact that in this passage there is one nature that is above and over other natures and responsible for them.

Every thing which is in a system is a cause ('illa) for what is below it, until [one] arrives at the one which is the cause of everything in that system altogether, and consequently, [this cause] is necessarily before the things which are in the system, and all of them proceed from it. Therefore, all of what is in that system is homogeneous, one genus is common to them and one exposition explains them. It has now been made evident by what we mentioned and follows clearly that the one and the many are in the nature of bodies, and that many natures hang (muta'alliq) on one nature, and that the many natures are from the nature of the one all (wa-'anna

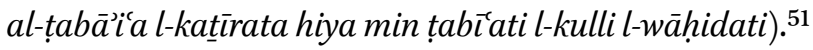

The principle that one nature is the source of and causes many adds the causal depth to the account needed to form a causally meaningful account of nature from the Procleana Arabica. Here it is the nature of the whole that grounds the many individual natures, each of which stems from and depends upon the prior, universal nature. We do read that, "Every thing which is in one system is a cause for what is below it," but here nature itself is not identified simply as a cause. Thus, one might still wonder as to the causal connection between the nature of the all and the individual natures, and want a more explicit discussion of nature in terms of causality. We find such an explanation of nature in Bāb 8 of the Liber de causis II.

The proof that this is true is that each one of the causes of things is a head (ra'sisiyya) of what resembles it and is suitable to it. The resemblance to it is like the intellect, insofar as it is a head of the intellectual forms because it is their cause, and it is like them and suitable to them. And similarly nature is the head of the natural things, because it is a cause for them and

$5^{1} \quad$ Endress 1973, p. 269, and the Arabic may be found on Ar. 20-21. 
a likeness for them. It was already made clear that each thing that receives definition is suited to its cause, so that if the cause is sovereign, the one is sovereign, and if the cause is psychical, then the one which is defined by it is psychical also, and if the cause is natural, the one which is defined by it is also natural. ${ }^{52}$

Here nature is listed as a 'illa, cause, and as ra'ssiyya, head or superior of those things that resemble it, viz. that are caused by it. The causal language clarifies that nature is both a cause, and a cause in the same way as the higher principles - not a cause of the same sort of things and unity, but a cause all the same.

We saw above that the things nature encompasses are generated things, some of which fall under the provenance of soul and some of which do not. In line with this account, we read in $B \bar{a} b 8$ that nature causes natural unities, and in Proposition 21 of the Proclus Arabus that each link in a system causes what comes after it, and that nature is a link that stands above individual natures. In the Liber de causis II Bāb 2, we also read that, unlike matter, nature has an active power, quwwa fa" äla by which it brings about effects in things beneath it, i.e. generated things. We saw in the beginning of this section that soul is said to govern nature by a divine power in it, and that intellect is also said to govern nature by a divine power. Further, nature is said is govern natural, generated things by a divine power within it. These connections may seem to be working at cross purposes, but if we consider these causal relations structurally, we find the following. Both intellect and soul govern nature by a divine power. Nature itself governs generation through either an intellectual power or a psychical power (or both). Soul is also said to be the cause of the motion of natural bodies. We then read the description of nature as a cause of individual natures and natural bodies. Rather than read these causal accounts as precluding an attribution of causal power and efficacy to nature, we ought to read them as laying out the causal network by means of which nature receives from the first cause its own causal power to ground, encompass, and take responsibility for individual natures and natural bodies. The causal grid does not leave any but the first cause bereft of causal force. Rather, it lays out a descending lattice that accounts for the ways in which subsidiary causes can specify, redirect, and channel the power from the initial and truest cause. The tension that results from this framework is the heart of the Neoplatonist universe. Understood in this way, nature in the Procleana Arabica is a case in point for Neoplatonic 
metaphysics. Nature gleans its power from the intellect and soul, both of which channel a divine power to nature, and nature directs its effects with the intellectual power it has within itself, which it also received from the previous causal levels.

In conclusion, I would like briefly to highlight two differences between the account of nature found in the Arabic Plotinus materials versus those in the Arabic Proclus materials, namely, the description of nature's activity and the discussion of nature as instrumental. In the Plotiniana Arabica materials, we find explicit discussion of the activity of nature as such, which is presented as a unique immanent level of psychic activity. In the Procleana Arabica, we do not find such a description. The reason we do not find a description of such immanent psychic activity—which is itself actually rather Proclean as presented in his Timaeus commentary - is precisely because only a small portion of that commentary was translated into and circulating in Arabic. ${ }^{53}$ Instead, all that was available from Proclus's remarks on nature are what had been translated from the Element of Theology, as a result of which the Arabic readers of Proclus received a different, or at least a more limited, view of Proclus's own theory of nature (as circulated under whatever name). The second difference is that the description of nature as instrumental, a serious point of contention and interpretative difficulty in the description of nature in the Arabic Plotinus materials, is not found at all in the Arabic Proclus materials. Although nature is said to be caused or governed by soul, never is it said to be an instrument of soul. Further, the attribution of instrumentality or mediation to a principle does not in itself reduce it to something without self-direction or inherent, independent power. The supreme case in point is intellect, a description that D'Ancona has considered at length. ${ }^{54}$ Above I emphasized that although nature is identified as soul's activities in the Arabic Plotinus materials, soul is also identified as intel-

\footnotetext{
53 Tarrant 2007, p. 103-106.

54 Consider, for example, Liber de causis I 8, Liber de causis II 22. This way of describing intellect is found throughout 'Abd al-Lațif's epitome. For a thorough discussion of the way in which intellect is said to be an intermediary, see D'Ancona 1995, p. 73-95. Describing all causes except the first as proximate or mediating causes may also be found in al-Kindi's The One True and Complete Agent, which can be found in McGinnis and Reisman 2007, p. 22-23.
} 
lect's activities, such that this way of talking about the causal chain is just one way of accounting for the production of a lower causal order by a higher one, and need not be understood reductively.

\section{Bibliography}

\section{Primary Sources}

Classical Arabic Philosophy: An Anthology of Sources, ed. J. McGinnis, D.C. Reisman, Indianapolis/Cambridge, Hackett, 2007.

Liber de causis: Al-Aflāțūnìya al-muhdatha inda al-'arab /Neoplatoniciapud Arabes, ed. 'A. Badawī, Cairo, 1955; rpt. Kuwait, Wakalat al-Matbu'āt, 1977.

Plotiniana Arabica: in Plotinus, Enneades IV-V, eds P. Henry, H.-R. Schwyzer, transl. G. Lewis, Paris / Brussels, Desclée de Brouwer, 1959.

Theologia Aristotelis: Aflūțin inda al-'arab / Plotinus apud Arabes. Theologia Aristotelis et fragmenta quae supersunt, ed. 'A. Badawī, Cairo, Maktabat al-nahḍa al-mișriyya, 1955 .

\section{Secondary Sources}

Adamson, P. (2017), The Arabic Plotinus: A Philosophical Study of the 'Theology of Aristotle', Piscataway, NJ, Gorgias Press.

Adamson, P., Karfík, F. (2017), "Proclus's Legacy," in P. d'Hoine and M. Martijn (eds), All from One. A Guide to Proclus, Oxford, Oxford University Press, p. 29o-323.

Arnzen, R. (2013), "Proclus on Plato's Timaeus 89e3-9oc7", in Arabic Sciences and Philosophy 23, p. 1-45.

Cureton, W. (1846), Muhammad ibn Abd al-Karīm al-Šahrastānī. Al-Milal wa-l-Niḥal, Part II, London, The Society for the Publication of Oriental Texts.

D’Ancona, C. (1995), Recherches sur le Liber de Causis, Paris, J. Vrin.

D'Ancona, C. (1999), "Porphyry, Universal Soul, and the Arabic Plotinus," in Arabic Sciences and Philosophy 9, p. 47-88.

D'Ancona, C. (2001), "Pseudo-Theology of Aristotle, Chapter 1: Structure and Composition," in Oriens 36, p. 78-85.

D'Ancona, C. (2004), "The Greek Sage, the Pseudo-Theology of Aristotle and the Arabic Plotinus," in R. Arnzen, J. Thielmann (eds), Words, Texts and Concepts Cruising the Mediterranean Sea, Leuven, Peeters, p. 159-176.

D'Ancona, C. (2006), "The Arabic Version of Enn. IV.7[2] and its Greek Model," in J. Montgomery (ed.), Arabic Theology, Arabic Philosophy. From the Many to the One: Essays in Celebration of Richard M. Frank, Leuven, Peeters, p. 127-156.

Endress, G. (1973), Zwanzig Abschnitte aus der Institutio Theologica in Arabischer Übersetzung, Beirut, Franz Steiner Verlag. 
Gerson, L. (2012), "Plotinus on logos," in J. Wilberding, C. Horn (eds), Neoplatonism and the Philosophy of Nature, Oxford, Oxford University Press, p. 17-29.

Janos, D. (2015), “'Active Nature' and Other Striking Features of Abū Bišr Mattā ibn Yūnus's Cosmology as Reconstructed from His Commentary on Aristotle's Physics," in D. Janos (ed), Ideas in Motion in Baghdad and Beyond. Philosophical and Theological Exchanges between Christians and Muslims in the Third / Ninth and Fourth / Tenth Centuries, Leiden, Brill, p. 135-177.

Lammer, A. (2018), The Elements of Avicenna's Physics: Greek Sources and Arabic Innovations, Berlin, De Gruyter.

Lernould, A. (2012), "Nature in Proclus: From Irrational Immanent Principle to Goddess," in J. Wilberding, C. Horn (eds), Neoplatonism and the Philosophy of Nature, Oxford, Oxford University Press, p. 68-102.

Martijn, M. (2010), Proclus on Nature: Philosophy of Nature and its Methods in Proclus's Commentary on Plato's Timaeus, Leiden, Brill.

Martini Bonadeo, C. (2013), 'Abd al-Lațif al-Baġdādìs Philosophical Journey: From Aristotle's Metaphysics to the 'Metaphysical Science', Leiden, Brill.

Martini Bonadeo, C. (2017), "The First 'Proclean' Section (Chapter 2o) of 'Abd al-Lațif alBağdādī's Book on the Science of Metaphysics. Is the Pure Good of the Mahd al-hayr Aristotle's First Principle, Intellect in Actuality?," in Oriens 45, p. 259-305.

Noble, C.I. (2013), "How Plotinus's Soul Animates His Body: The Argument for the SoulTrace at Enn. IV.4(28).18.1-9," in Phronesis 58.3, p. 249-279.

Opsomer, J. (2017), "The Natural World," in P. d'Hoine, M. Martijn (eds), All from One: A Guide to Proclus, Oxford, Oxford University Press, p. 139-166.

Rosenthal, F. (1952), "Aš-Šayh al-Yūnānī and the Arabic Plotinus Source," in Orientalia 21, p. 461-492.

Rosenthal, F. (1953), "Aš-Šayh al-Yūnānī and the Arabic Plotinus Source (Continued)," in Orientalia 22, 4, p. 370-400.

Rosenthal, F. (1955), "Aš-Šayh al-Yūnānī and the Arabic Plotinus Source (Concluded)," in Orientalia 24, 1, p. 42-66.

Tarrant, H. (2007), Proclus. Commentary on Plato's Timaeus, vol. 1, Cambridge, Cambridge University Press.

Taylor, R. (1984), “Abd al-Latif al-Baġdādī’s Epitome of the Kalām fì maḥ̣ al-khayr (Liber de causis)," in M. Marmura (ed.), Islamic Theology and Philosophy: Studies in Honour of George F. Hourani, Albany, State University of New York Press, p. 236-323.

Thillet P., Oudaimeh, S. (2001-2002), "Proclus Arabe. Un Nouveau Liber de causis?," in Bulletin d'études orientales 53/54, p. 293-367.

Wakelnig, E. (2006), Feder, Tafel, Mensch:Al-Āmirīs Kitāb al-Fusūl fīl-Ma ālim al-ilāhīya und die arabische Proklos-Rezeption im. 10.Jh., Leiden, Brill.

Wakelnig, E. (2012a), "Proclus in Aristotelian disguise: Notes on the Arabic transmission of Proclus's Elements of Theology," in Universalità della Ragione III, p. 165-176. 
Wakelnig, E. (2012b), “The Other Arabic Version of Proclus's De Aeternitate Mundi. The Surviving First Eight Arguments," in Oriens 40, p. 51-95.

Wakelnig, E. (2013), Ps-Aristotle. Kitāb al-Haraka, sAws edition, on http://www.ancient wisdoms.ac.uk/cts/urn:cts:sawsTexts:HME5683.KHar.sawso1.

Wakelnig, E. (2014), A Philosophy Reader from the Circle of Miskawayh, Cambridge, Cambridge University Press.

Wildberg, C. (2009), "A World of Thoughts: Plotinus on Nature and Contemplation (Enn. III.8(30).1-6)," in R. Chiaradonna, F. Trabattoni (eds), Physics and Philosophy of Nature in Greek Neoplatonism Leiden, Brill, p. 121-143.

Zimmermann, F.W. (1986), "The Origins of the so-called Theology of Aristotle," in J. Kraye, C.B. Schmitt, W.F. Ryan (eds), Warburg Institute Surveys and texts XI:PseudoAristotle in the Middle Ages, London, Warburg Institute, p. 110-240.

Zimmermann, F.W. (1994), "Proclus Arabus Rides Again," in Arabic Sciences and Philosophy 4, p. 8-51. 